\title{
EL MONACATO PRIMITIVO: ¿VEHÍCULO DE DESINTEGRACIÓN SOCIAL? \\ (ALGUNOS ASPECTOS DEL PROBLEMA A LA LUZ DE LAS FUENTES LITERARIAS Y JURÍDICAS)
}

\author{
POR \\ José Emilo Martínez Tur \\ Universidad Complutense de Madrid
}

\section{RESUMen}

El presente artículo aborda el problema de la incidencia del monacato primitivo en la sociedad, en la vida urbana, en la cultura pagana y en la estructura social del mundo tardorromano.

\begin{abstract}
The study here exposed tries to give a approache to the problem of the incidence of the primitive monachism in the society, in the urban life, in the pagan culture and in the social structure of the late-roman world.
\end{abstract}

\section{INTRODUCCIÓN}

En la presente comunicación abordaremos uno de los muchos problemas que el monacato primitivo plantea: el de su incidencia en la sociedad que lo vio nacer. Partiendo de una exposición muy somera sobre la situación en que se encontraba la Romania cuando el monacato se presentó al mundo bajorromano, apuntamos luego los tres elementos que, en nuestra opinión, lo convirtieron en un vehículo de inestabilidad social: a) sus ideales, alimentados por la espiritualidad que desarrollaron los grandes mentores de la vida monástica, b) la irresistible atracción que dichos ideales ejercieron sobre grandes masas de 
población y c) las adversas condiciones de la época. A pesar de que otorgamos al plano religioso y espiritual un importante papel en la vocación de aquellos primeros monjes, no dejamos de ponerlo en relación con los factores coyunturales del período, pues consideramos que cualquier idea, pensamiento o aspiración siempre se hallan influidos, si es que no están motivados, por el entomo en que surgen'. Por tanto, no podemos estar sino de acuerdo con el profesor Teja cuando advierte sobre la inconveniencia o inexactitud de abordar el estudio del monacato primitivo desde un punto de vista exclusivamente espiritual, según han venido haciendo muchos autores ${ }^{2}$.

De ahí que en el presente trabajo centremos nuestra atención en tales factores coyunturales pues consideramos que en ellos es donde debe buscarse la clave explicativa del espectacular desarrollo que el monacato experimentó entre el último tercio del siglo III y los años finales del IV. De esta expansión, a su vez, se derivó la peligrosidad del monacato como fenómeno histórico. Se trataba, en definitiva, de una cuestión de número, de multitudes y, por supuesto, de extracción social pues, a pesar de las protestas que algunos elevaron, ninguna institución legisló para impedir la entrada en las filas monásticas de los miembros pertenecientes a las élites de la sociedad bajoimperial, o contra las de aquellos otros que, al abandonar, su actividad profesional no ponían en peligro la continuidad del orden establecido. Es decir, para ingresar en el monacato durante el Bajo Imperio no era lo mismo ser curial o esclavo que, pongamos por caso, joyero o bandido.

Para estudiar la incidencia que tuvieron los ideales monásticos en a sociedad de aquel período hemos elegido tres de los muchos aspectos que el monacato cuestionó: la vida urbana, la cultura pagana y la rígida estructura social del mundo tardorromano. Han sido éstos, y no otros, porque consideramos que fueron parte esencial de las tradiciones y de la organización interna del Bajo Imperio. A través de una selección de textos literarios y jurídicos de la época, los iremos analizando, antes de ofrecer unas breves conclusiones.

1 Mario Mazza ha puntualizado recientemente que la principal limitación del trabajo de A. D. NocK (Conversion. The Old and the New in Religion from Alexander the Great to Augustine of Hippo, Oxford, 1933) se halla, precisamente, en el hecho de no haber tenido en cuenta, dentro de su análisis sobre el fenómeno de las conversiones, otros elementos al margen de los estrictamente individuales y religiosos. Y ello, según Mazza, «perchè «conversione» è certo «riorientamento» della psiche individuale, ma è anche una «scelta» sulla quale influiscono in maniera altamente significativa, $\mathrm{e}$ talora anche determinante, certamente fattori religiosi, ma forze fattori in generale «sociali», elementi in ogni caso esterni all'individuom; M. MAZZA, «La conversione nella Tarda Antichità. Appunti per una fenomenologia», en La Historia en el contexto de las ciencias humanas y sociales. Homenaje a Marcelo Vigil Pascual (Santander, 1989), p. 126.

2 R. TEJA, «Monacato e historia social: los orígenes del monacato y la sociedad del Bajo Imperio Romano», en La Historia en el contexto..., pp. 82-83.

$I^{\text {Ts }}$ Congreso de Historia de la Iglesia Hispania Sacra 51 (1999) 
El monacato primitivo fue una realidad compleja, multiforme y, sobre todo, llena de paradojas; tantas como las que poseía la sociedad que lo viera nacer. Impulsado por una espiritualidad peculiar y por una serie de ideales claramente contrapuestos a los valores ya asentados con firmeza en el mundo tardorromano, cuando el monacato se convirtió, además, en un fenómeno de masas «lo que ocurrí en un cortísimo período de tiempo», su potencialidad «revolucionaria», si se nos permite la expresión, alcanzó niveles muy preocupantes, al menos hasta el momento en que se inició el proceso de su institucionalización, merced a la legislación canónica emanada del concilio calcedonense de 451. Refugio de temperamentos rigurosos y exigentes, de místicos, de inconformistas, de marginados y de ascetas, el monacato primitivo puso en duda los principios y valores en que se asentaba el orden establecido en el Bajo Imperio. De ahí que amplios sectores de la sociedad bajorromana, tanto cristianos como paganos, vieran en la vida monástica una auténtica amenaza que, según su grado de oposición a la misma, debía ser erradicada para siempre o regulada en sus manifestaciones más preocupantes ${ }^{3}$.

Muchos contemporáneos del monacato primitivo entendieron que sus ideales, como grado extremo de la vivencia cristiana, encerraban peligros de consecuencias imprevisibles. Uno de ellos, quizá el más significativo de todos, dada su particular trayectoria vital fue el emperador Juliano, que percibió con claridad los desastrosos resultados que podrían producirse al aplicar, en toda su literalidad, la máxima evangélica de renuncia al mundo que había inspirado la vocación monástica del mítico Antonio. A este respecto, y en el contexto más amplio de su oposición al cristianismo, decía: «Escuchad un bello y político consejo: «Vended vuestros bienes y dádselos a los pobres; haceos bolsas que no envejezcan» ¿Quién puede decir algo más político que esta orden? Porque si todos le obedecieseis, ¿quién sería el comprador? ¿Quién alaba esta enseñanza que, si se impusiera, no se mantendría ni una ciudad, ni un pueblo, ni una sola casa? Pues si todo hubiera sido vendido, ¿cómo podría existir una casa o familia digna? (Contra Galileos. Fragmentos 5).

3 Sobre la consideración social del monacato y las corrientes contrarias al mismo en estos primeros siglos, cf. P. DE LABRIOLLE, «Les débuts du monachisme», en A. FuICHE y V. MARTIN (dirs.), Histoire de l'Église (París, 1945), pp. 299-369 (hay trad. española bajo la dirección de J. M" JAVIERRE, Historia de la Iglesia, Valencia, 1977, vol. 3, pp. 329-404); H. JEDIN (dir.), Manual de Historia de la Iglesia, Barcelona, 1990, vol. 2, pp. 531-536 (la ed. original alemana, publicada en dos volúmenes, es de 1973-1975); G. M. CoLombÁs, El monacato primitivo, 1. Hombres. Hechos, Costumbres. Instituciones, Madrid, 1974, pp. 330-365; R. TEJA CASUSO, «Los orígenes del monacato y su consideración social», Codex Aquilarensis, 2 (1989), pp. 11-31; idem, «Los monjes vistos por los paganos», Codex Aquilarensis, 16 (1993), pp. 9ss. G. RINALDI, «Obiezioni al monachesimo de parte de pagani ni area mediterranea (secoli IV e V)» en XXII Incontro di Studiosi dell'antichitá cristiana: cristianismo especifitá regionali nel Mediterraneo latino (sec. $V$ - $V I$ ), Roma, 1994, pp. 31-82. 
En momentos especialmente graves para la continuidad del Imperio, cuando el Estado romano reclamaba de sus súbditos toda la colaboración posible —con métodos ciertamente brutales la mayoría de las veces--un número considerable de individuos decidió abandonar sus títulos, sus propiedades y, sobre todo, sus responsabilidades hacia el Estado, para ir a enterrarse en el desierto a fabricar esteras y cestas. Este comportamiento resultó intolerable para muchos y, en nuestros días, no han faltado opiniones de algunos especialistas destacando el carácter incívico del monacato y el egoísmo de que hicieron gala los primeros monjes y sus defensores ${ }^{4}$.

La sociedad que vio nacer el monacato estaba escindida y golpeada por problemas de muy diversa índole; los religiosos no fueron, desde luego, los menos importantes, aunque ocultaran en el fondo problemáticas de más largo alcance, como, por ejemplo, el modo en que debía reconstruirse la sociedad romana surgida de la profunda crisis del siglo III, qué bases teóricas -clásicas - cristianas- debían emplearse para llevar a cabo dicha reconstrucción, etc. Se trataba, en definitiva, de dos actitudes distintas y opuestas ante la vida, de dos concepciones existenciales que alcanzarían un considerable grado de radicalización cuando el cristianismo se convirtió en la religión preeminente del Imperio. Desgraciadamente, el valor político del monacato fue nulo -aunque su mensaje, como ya hemos visto, no careciese de consecuencias políticas-, por lo que resultó inviable la posibilidad de congraciar los ideales moribundos del paganismo clásico con los de la nueva y triunfante enseñanza cristiana ${ }^{5}$. En lugar de reducir las tensiones que se padecían en el Imperio, el monacato -con su total desprecio del mundo y su entrega absoluta a Dios y a la salvación personal-contribuyó a elevar el nivel de esquizofrenia de la sociedad tardorromana. Su receta, exclusivamente espiritual y escatológica, nada tenía de positivo para los dirigentes del Estado, fueran o no cristianos. No resulta extraño, por tanto, que el emperador Juliano comparase a los monjes con los falsos cínicos paganos a quienes denunciaba en uno de sus discursos (Oratio 7: contra el cínico Heraclio, 224, a y c).

Pero a pesar de sus numerosos detractores, a finales del siglo IV el monacato ya era una realidad pujante que no podía pasar desapercibida entre sus contemporáneos. Para entonces quedaban muy lejos los tiempos en que el egipcio Antonio se había iniciado en la práctica anacorética, abriendo el camino hacia el «gran desierto» como residencia permanente del monje. La poste-

4 Cf. R. TEJA, «La Iglesía y la economía en el siglo IV. La doctrina económíca de los Padres Capadocios", Revista de la Universidad de Madrid, 20, 79 (1971) pp. 117-118. En sentido contrario, G. M. COLOMBÄS, op. cit., pp. 351ss.

5 Ch. N. Cochrane, Cristianismo y cultura clásica, Madrid, 1983 (la ed. original inglesa es de 1939), p. 334.

$I^{\text {er }}$ Congreso de Historia de la lglesia Hispania Sacra 51 (1999) 
rior hagiografización de su vida, en el que puede ser considerado el libro de cabecera de los monjes primitivos la Vita Antonii escrita por Atanasio de Alejandría, y el fulgurante éxito que conoció esta obrita en los círculos ascéticos de Oriente y Occidente contribuyeron a engrandecer la figura del santo anacoreta y a propagar los ideales representados por su persona ${ }^{6}$. Después de Atanasio, otros importantes mentores de la vida monástica continuaron desarrollando los ideales teóricos que, con tanto acierto, perfilara él en su obra. Personajes como Basilio de Cesarea, Gregorio de Nisa, Juan Crisóstomo o Evagrio Póntico en Oriente, y Jerónimo de Estridón, Agustín de Hipona o Juan Casiano en Occidente se ocuparon de dar al monacato el impulso espiritual definitivo? Sus elaboraciones teóricas y las adversas condiciones de la época actuaron como poderosos revulsivos: un número ingente de hombres y mujeres, procedentes de los sectores sociales más heterogéneos, abandonaron el mundo y fueron a enterrarse voluntariamente, en los lugares más insospechados, solos o en compañía de otros ${ }^{8}$.

Como acabamos de ver, lo que podríamos denominar la «paradoja monástica» poseía dos niveles diferentes de amenaza contra el orden establecido en el Bajo Imperio: el primero se movió en un plano teórico y religioso, espiritual, y

6 Sobre Atanasio y su obra, cf. J. QUASTEN, Patrología II. La edad de oro de la literatura patrística griega, Madrid, 1994, pp. 23-85. Un estudio de la Vita Antonii en L. BOYEUR, La vida de Antonio. Ensayo sobre la capitularidad del monacato primitivo, Monasterio de las Huelgas (Burgos), 1989. Se verá además, las siguientes ediciones de dicha biografía: G.J.M. BARTELiNK, Athanase d'Alexandre. Vie d'Antonie ( $«$ Soucres Chretienns», 400), París, 1994 (ed. Y trad. de la versión griega de la Vita; Ch. MOHRMANN et ali, Vita di Antonio, Roma, 1987 (ed. y trad. de la versión latina anónima); P. RUPÉREZ, Atanasio. Vida de Antonio, Madrid, 1994 (Trad. de la versión griega, teniendo en cuenta las variantes presentes en la versión latina).

7 Un estudio particular sobre cada uno de estos autores puede verse en la obra colectiva Théologie de la vie monastique. Études sur la tradition patristique (París, 1961). Para Evagrio Póntico, cfr. A. y C. GulllaumONT, «Évagre le Pontique», en Dictionnaire de Spiritualité, Ascétique et Mystique, Doctrine et Histoire (Paris), 4 (1961), 1731-1744; J. QUASTEN, Patrologia, II, pp. 184-193; J. I. GONZÁLEZ, «Introducción» a Evagrio Póntico. Obras espirituales. Tratado práctico a los monjes. Exhortación a una virgen. Sobre la oración, Madrid, 1995, pp. 13-130. Una síntesis sobre la doctrina espiritual de todos estos autores y de algunos otros puede verse en G. M. COLOMBÁs, El monacato primitivo II. La espiritualidad, Madrid, 1975, pp. 33-75.

8 Así lo demuestran las fuentes conservadas, cuyas cifras con todas las reservas que puedan merecemos, y aun siendo may variables, si comparamos las que corresponden a Oriente con las de Occidente nos hablan de miles de personas entregadas al ideal monástico. Como botón de muestra para las tierras egipcias y palestinas, cfr. PALADIO, Historia Lausiaca, 7, 13, 20, 32, 48 y 58. Sobre la composición social del primitivo monacato puede verse G. PENCO, «La composizione sociale delle comunità monastiche nei primi secoli», Studia Monastica, 4, fasc. 2 (1962), pp. 257-281; A. M. GONZÁlEZCoBos, «Sobre los condicionamientos sociales de los origenes del monacato», Hispania Antiqua, 3 (1973), pp. 135-152; J. M BLÁZQUEZ, «Extracción social del monacato primitivo, siglos IV-VI», en Intelectuales, ascetas y demonios al final de la Antiguiedad (Madrid, 1998), pp. 345-365 (publicado originalmente en 1988). 
fue elaborado, a partir de los principios contenidos en el Evangelio, por los mentores del monacato que, en su mayor parte, procedían de las clases superiores de la sociedad bajorromana. El segundo nivel, mucho más peligroso que el anterior, se materializó en la «sangría» humana que el monacato ocasionó en la sociedad bajoimperial y en las consecuencias de todo tipo que se derivaron de ella. En este caso, los protagonistas fueron generalmente individuos que procedían de los grupos sociales más desfavorecidos o descontentos del mundo tardorromano (esclavos, colonos, campesinos, artesanos, funcionarios, curiales, etc.), lo que se explica, en parte, por la propia estructura demográfica de la sociedad tardoimperial. No cabe duda que fue la conjunción de ambos factores «unida a las condiciones de la época» la que otorgó al monacato su potencial peligrosidad. La dialéctica que enfrentó a los detractores y partidarios de la vida monástica se desarrolló en torno a conceptos y principios muy concretos: los que se derivaban del hecho de ser el monacato la antítesis de los valores arraigados en la sociedad bajorromana. A la vida urbana, los monjes opusieron el retiro al desierto; al antropocentrismo y mundanidad de la cultura pagana, la sola sabiduría divina; al lujo, la riqueza y los honores del siglo, el ascetismo y la pobreza; a la rígida jerarquización social, el igualitarismo cristiano; al otium y a la existencia disipada, el trabajo y la oración continuos; a la vida regalada, la penitencia; al egoísmo, la caridad para con el prójimo; al acatamiento de las estructuras vigentes y de las jerarquías, la insumisión ${ }^{9}$.

En las líneas que siguen vamos a centrar nuestra atención en los tres rasgos fundamentales ya enumerados: el rechazo de la vida urbana, el desprecio por la cultura y el igualitarismo social (más retórico que real) defendido por el monacato y sus mentores.

\section{a) La ciudad y los monjes}

«[Antonio] convenció a muchos para que eligieran la vida solitaria. Surgieron así monasterios en los montes y el desierto se hizo una ciudad de monjes que habían abandonado sus propiedades e imitaron la manera de vida del cielo» (Vit. Ant., 14, 7).

En este pasaje de la Vida de Antonio y en la larga exhortación que, acto seguido, lanzó el gran anacoreta egipcio a petición de los monjes que le seguían $(16,1-43,3)$ encuentra Derwas J. Chitty la institucionalización del monacato ${ }^{10}$. « ¿Una ciudad en el desierto? ¿El paraíso localizado en las agrestes soledades?»

9 Cf. J. M. BLÁZQUEZ, «El monacato de los siglos IV, V y VI como contracultura civil y religiosa», en Intelectuales, ascetas..., pp. 221-255 (publicado originalmente en 1989).

10 El desierto juna ciudad!, Bilbao, 1991, p. 20 (la edición original inglesa en Oxford, 1966).

$I^{\text {er }}$ Congreso de Historia de la Iglesia

Hispania Sacra 51 (1999) 
Una gran paradoja parece vislumbrarse en este «credo» de la existencia monástica que es la Vita Antonii.

La historia del mundo clásico había sido la de las ciudades. En el siglo II de nuestra era, en plena monarquía ilustrada de los Antoninos, el sofista Elio Arístides se hacía eco de esta realidad declarando que el orbe entero, sometido a Roma, era un Estado-ciudad ${ }^{1}$. La cultura, el ocio y el negocio, la civilización en fin, resultaban inconcebibles al margen de la vida urbana, y ello a pesar de que la mayoría de la población residía fuera de las ciudades. Si fue posible gobernar un imperio tan vasto como el romano es porque se hizo a través de las civitates, verdaderas arterias del mismo. Y lo cierto es, que tras la crisis del siglo III, la ciudad que conociera Arístides ya no era la misma; su concepto y sus espacios habían sufrido un profundo cambio, resultado de las nuevas circunstancias, y el cristianismo no había jugado en ello un pequeño papel. De hecho, cuando el Imperio llegaba a su fin y los bárbaros penetraron en él tuvieron la oportunidad de comprobar que, al frente de'las ciudades, se hallaba el obispo, y no las antiguas curias municipales, hacía tiempo anruinadas. Pero a pesar de los cambios, el espíritu de la ciudad «ahora restaurada» permanecía vivo en la mente de la sociedad bajorromana, y aunque el proceso de ruralización del Imperio era cada vez más palpable, ni el Estado, ni la Iglesia «que se había extendido gracias a las ciudades», ni, por supuesto, los defensores del paganismo postrero, tenían la menor intención de renunciar al ideal urbano. La civilización y la humanitas todavía resultaban inconcebibles al margen de las ciudades.

La aparición del monacato puso en entredicho todo esto, al rechazar el papel de la ciuitas como unidad social y cultural. «Los monjes [...] siguen una tradición cristiana muy diferente, casi podríamos decir que arcaica. Sus actitudes espirituales y morales se alimentaban de la experiencia de un entorno rural muy distinto al de los cristianos urbanos» ${ }^{12}$. De este modo, frente al ideal de la ciudad, el monacato quiso implantar la sinrazón de la huida al desierto, hábitat hostil por antonomasia para el desarrollo material y espiritual del hombre.

Para los paganos, este comportamiento resultaba irritante e incomprensible. ¿Qué sentido tenía esta misantropía descabellada, cuando todo lo bueno y deseable para el verdadero ser humano se podía encontrar precisamente en las ciudades? En su carta al gran pontífice pagano Teodoro, Juliano le hacía partícipe de lo que para él era una inexplicable contradicción: «Hay también quienes persiguen los desiertos en lugar de las ciudades, y eso que el hombre es por naturaleza un animal ciudadano y civilizado, entregados a démones mal-

11 J. M. RostovtZEFF, Historia social y económica del Imperio Romano, Madrid, 1981, vol. I, pp. 261-263.

12 P. BROWN, «La Antigüedad Tardía. El monacato», en Ph. ARIÉS y G. DUBY (dirs.), Historia de la vida privada, 1: Imperio romano y Antigiedad tardia, Madrid, 1991, p. 279. 
vados que les conducen hacia esta misantropía. La mayoría de ellos ya han inventado cadenas y grilletes que aprisionan los cuellos; hasta tal punto les empuja por doquier el perverso demon al que se han entregado voluntariamente, renegando de los dioses eternos y salvadores» (Epistola 89b).

Pero lo peor de todo no era que los monjes abandonaran las ciudades en nombre de no se sabe qué loco ideal, sino que, al socaire de servir a Dios, muchos volvían a ellas y ocasionaban graves problemas de orden público, participando en actos tumultuarios, interfiriendo la labor de la justicia o provocando disturbios callejeros de toda índole ${ }^{13}$. Especialmente lamentable fue el papel de los monjes en la destrucción de los templos paganos y de las sinagogas judías, o el fanatismo de que hicieron gala en las frecuentes luchas de todo tipo que enfrentaron a los propios cristianos ${ }^{14}$. Con una Iglesia progresivamente robustecida y un Estado

13 Para evitar este tipo de comportamientos, y hacer que los monjes fueran consecuentes con su propio apelativo de «solitarios»-circunstancias que ya les había reprochado el gramático pagano Palladas de Alejandría (Epigrama 528) —, la autoridad imperial promulgó el 30 de septiembre de 390 una ley por la que se ordenaba a los monachi que abandonasen las ciudades para marchar «deserta loca et vastas solitudines» (Cod. Theod., 16, 3, 1). La oposición a esta medida «que muestra el creciente peso que el monacato estaba adquiriendo en la sociedad bajorromana y la protección que le dispensaban algunos obispos» fue muy fuerte pues, dos años despues, una nueva ley (Cod. Theod., 16, 3,2 ) revocaba la anterior, permitiendo a los monjes que permanecieran en las ciudades, si ése era su gusto. El cristianísimo Teodosio intentó justificar su primera decisión «de indudable carácter policial» afirmando ahora que había sido mal informado. Las legislaciones eclesiástica y secular retomaron posteriormente la prohibición del año 390 sobre la permanencia de los monjes en las ciudades; así, por ejemplo, Conc. Chalced., c. 4 (se sobreentiende) y 23 (que les niega su estancia en Constantinopla) y Cod. lust., 1, 3, 29 (para Antioquía y otras ciudades). Sobre la injerencia de los monjes en la justicia, cf. entre otros Vita Antonit, 46, 3 y Cod. Theod., 9, 40, $16(=11,36,31)$.

14 El caso más célebre de lo primero lo tentemos en la ofensiva que lanzó el obispo Teófilo de Alejandría en 391, y que coincidió en el tiempo con un edicto imperial que sólo prohibía los cultos paganos en Egipto y la visita a sus templos (cf. Cod. Theod., 16, 10, 11). Con el apoyo de los monjes egipcios ( $\mathrm{e}$ interpretando a su voluntad dicho edicto?). Téfilo ordenó abatir el famoso Serapeion alejandrino y otros templos, entre ellos el de la ciudad de Canope (cf. EUNAPIO, Vitae Sophista rum, 6, 11, 1-10; Apophthegmata Patrum, Teofilo, 3 y Epifanio, 2). Esta violencia monástica antipagana debio extenderse a los territoria de las ciudades a partir del año 399 , cuando otro edicto imperial ya dispaso expresamente que fueran demolidos los templos paganos localizados en el campo; y ello a pesar de que se ordenaba llevar a cabo la tarea «sine turba ac tumultu» (Cod. Theod, 16, 10, 16. Una mención a este tipo de leyes puede verse en Apophtheg. Patr. Besarión, 4 [= Verba Senionum 12, 3]). Para todo este problema cfr. G. FERNÁNDEZ, «Destrucciones de templos en la Antigüedad Tardía», Arch. Esp. Arq., 54, nos 143-144 (1981), pp. 141-156 y J. F. JORDÁN, «La pervivencia del paganismo en el reinado de Honorio (395-423 d. C.)» en Antigüedad y Cristianismo, 8 (Murcia, 1991), pp. 183199, que ofrece una exposición sobre el acoso al paganismo en general.

En el caso de los ataques contra las sinagogas judías el incidente más conocido es el que tuvo lugar en la ciudad de Callinicum, donde en 388 y con la aquiescencia del obispo católico, los monjes y el pueblo destruyeron la sinagoga de la ciudad. Teodosio ordenó que la reconstrucción del templo se hiciera a costa del consentidor obispo católico. Pero la medida «muy ecuánime, por otra parte» le costó al emperador enfrentarse con Ambrosio de Milán, para terminar cediendo ante el obispo (cfr. AMBRos10, Epistolae 40 y

$\mathrm{I}^{\mathrm{er}}$ Congreso de Historia de la Iglesia

Hispania Sacra 5 I (I999) 
cada vez menos proclive a la tolerancia, los monjes, y muchos obispos que se sirvieron de ellos para llevar a cabo estos desmanes, debieron entender que tenían vía libre para implantar cuanto antes el «reino de Dios» en la tierra.

Y ya fuera por el desprecio que demostraba hacia las ciudades, ya por el lamentable espectáculo que muchos monjes daban cuando hacían acto de presencia en ellas, el monacato aparecía como una amenaza real para la vida urbana y la estabilidad social en general. ¿Qué ocurrió en otros ámbitos? Algo parecido, como veremos inmediatamente.

\section{b) La cultura y el monacato primitivo}

De poco iban a servir las leyes promulgadas contra la turba monástica si lo que se pretedía con ellas era frenar el celo de unos monjes a quienes el obispo platónico Sinesio de Cirene había catalogado como «bárbaros que desprecian la obra literaria» (Dion, $3,9,13)$. Y es que, en efecto, la mayoría de los individuos que engrosaron las filas del monacato primitivo procedían de las capas más humildes e iletradas de la sociedad bajoimperial. Por supuesto que no faltaron ejemplos de lo contrario «ahí están, para demostrarlo, los casos de Evagrio Póntico, Arsenio, Basilio, Jerónimo, Agustín, Paulino de Nola, Paladio, Casiano, o el círculo de vírgenes del Aventino», pero se trató sólo de excepciones en medio de un panorama de evidente y perniciosa rusticidad.

A pesar de las consecuencias que podían derivarse de esta falta de instrucción, los teóricos del monacato «generalmente buenos conocedores de la cultura clásica» siempre manifestaron hacia ella su más enérgico rechazo. En este sentido, no es raro que un autor como Agustín reconociera en sus escritos sentirse arrepentido por haber dedicado demasiado tiempo al estudio de las letras profanas ${ }^{15}$.

41). En este sentido, es casi seguro que la ya nencionada ley 16, 3, 1 (cfr. supra nota 13) fuera promulgada tras la desagradable experiencia que el emperador babía tenido a causa del incidenie de Callinicum. Para el caso de Hispania, entre los años 417-418, tenemos un testimonio de violencia monástica antisemita en una carta debida al obispo Severo de Menorca, que ha sido editada y estudiada por G. SEGUí, La carta encíclica del obispo Severo. Estudio crítico de su autenticidad e integridad con un bosquejo histórica del cristianismo balear anterior al siglo VIII, Roma-Palma de Mallorca, 1937 (una síntesis de los problemas de autenticidad que ha planteado esta fuente, cuya cronologia han retrasado algunos autores hasta el siglo VII, puede verse en M. SOTOMAYOR, «La Iglesia en la Espaīa romana», en Historia de la Iglesia en España, 1. La Iglesia en la España romana y visigoda, Madrid, 1979, pp. 355-365).

Sobre el papel de los monjes en las querellas cristianas, especialmente durante el enfrentaniento origenista, cfr. Zósimo, Historia Nova, 5, 23 y JUAN CRISósTomo, Epist. 14, 2ss. Jerónimo (Epist. 17) se declaró víctima del fanatismo doctrinal con que se condujeron algunos monachi respecto a su teología trinitaria. Una exposición general de todo este problema en G. M. ColOMBÁs, El monacato..., I, pp. 309-330.

15 Retractationes, 1, 3, 4. En el fondo, el problema del rechazo de la cultura pagana siempre estuvo latente, desde sus origenes, en el cristianismo, dentro del cual coexistieron dos tendencias: la primera, 
El único y verdadero camino para llegar a Dios estaba en la Sagradas Escrituras. A estimular su estudio y su conocimiento profundos debían encaminarse todos los esfuerzos del monje, y sabio era considerado aquél que conocía al pie de la letra el texto sagrado ${ }^{16}$. Al referirse a Serapión el Sindonita, Paladio nos dice que «era un hombre muy culto: había aprendido de memoria las Sagradas Escrituras» (Hist. Laus., 37). El anacoreta Diocles «versado en la gramática y la filosofía» había decidido renunciar al ciclo de los estudios profanos para consagrarse por entero a Cristo. Solía sentenciar con frecuencia: «La inteligencia que se aparta del pensamiento de Dios se toma demonio o bestia» (Hist. Laus., 58). Los ejemplos podrían multiplicarse.

Pero aún había monjes que ni siquiera veían con buenos ojos este ejercicio intelectual sobre las cosas divinas; en su opinión, la sabiduría más sublime era la carismática; esto es, la que «merced a una vida santa y piadosa y a una espiritualidad más vivida que razonada» convertía al monje en theodidaktos o «instruido por Dios» ${ }^{17}$. Éste es el retrato que Atanasio nos ofrece de Antonio quien, a pesar de ser un iletrado, derrotó dialécticamente a unos presuntuosos filósofos paganos con la siguiente afirmación categórica: «¿Qué decís? ¿Qué es anterior, la mente o las letras? ¿O quién causa del otro, la mente de las letras o las letras de la mente?». Y ellos respondieron que la mente es anterior a las letras, y ella las ha inventado. Antonio añadió: «El que tiene la mente sana, no necesita las letras»» (Vit. Ant., 73, 2-3). Y es que, según Atanasio, la palabra de Antonio «estaba sazonada por la sal divina» (Vit. Ant., 73, 4). En los Apotegmas se han conservado algunas sentencias que demuestran el afecto de los padres del desierto por este tipo de sabiduría empírica y carismática: «Un día el padre Arsenio sometió sus pensamientos a un padre egipcio. Uno que lo vio le dijo: 'Padre Arsenio, ¿cómo es que tú, que posees una cultura greco-romana, interrogas sobre tus pensamientos a este tontaina?' $\mathrm{Y}$ respondió: 'Es cierto,

partidaria de asimilarla, estuvo liderada por autores como Justino, Clemente de Alejandría, Orígenes o Basilio; la segunda, con Tertuliano o el monacato a la cabeza, la repudiaba. La biografía sobre las relaciones entre cristianismo y cultura pagana - y sobre la recepción de ésta por el primero-es muy amplia. Remitimos solo a Ch. M. CoCHRANE, op. cit., Supra, nota 5; O. GiGON, La cultura antigua y el cristianismo, Madrid, 1970; y E. BOLISAN, La cultura pagana nei primi padri latini, Padua, 1964. Una buena síntesis del entomo cultural, religioso y filosofico del cristianismo en sus primeros siglos de existencia puede verse en J. ALVAR et alii, Cristianismo primitivo y sectas mistericas, Madrid, 1995.

16 Un ejemplo de lo que decimos puede comprobarse en las instrucciones que Jerónimo dio en algunas de sus cartas, redactadas para guiar la educación de tiernas niñas que, desde su nacimiento, estaban consagradas a Dios. En su Epistola 107 , por ejemplo, se traza un programa educativo que no deja ningún cabo suelto: régimen alimenticio, vestuario, lectio divina, labores domésticas, etc. Todo ello en el marco de una formación estrictamente cristiana y, en concreto, monacal. Sobre la cultura de los monjes primitivos, cf. A.-J. FESTUGIÉRE, Les moines d'Orient, It culture ou sainteté? Introduction au monachisme oriental, París, 1961.

17 G. M. COLOMBÁs, El monacato..., I, p. 306.

$I^{\text {er }}$ Congreso de Historia de la Iglesia

Hispania Sacra 51 (1999) 
poseo la cultura greco-romana, pero aún no he aprendido el alfabeto de este simple campesino' (Apop. Pat., Arsenio, 6).

No hace falta decir que este rechazo hacia la cultura profana «defendida ya por la antigua apologética cristiana de un Tertuliano, por ejemplo» también contribuy 6 a incrementar el desprecio que los autores paganos manifestaron hacia los monjes. De nuevo es Juliano quien, refíriéndose a este asunto dentro de sus ataques contra el cristianismo, se pregunta qué hay de bueno en tan inconsciente postura: «también sabéis vosotros, según creo, la diferencia respecto a la inteligencia de vuestras escrituras comparadas con las nuestras, y cómo gracias a las nuestras todo hombre podría superarse a sí mismo aunque esté totalmente desprovisto de cualidades naturales [...]. La prueba de ello es evidente: escoged hijos de todos vosotros y preparadlos en vuestras escrituras; si al llegar a la edad varonil alguno parece mejor que los esclavos, pensad que digo tonterías y que tengo la bilis negra. Además, sois tan desgraciados e insensatos que consideráis divinos aquellos tratados por los que nadie podría hacerse más sensato ni más valiente ni mejor que sí mismo; en cambio, aquellos por los que es posible adquirir la valentía, la inteligencia y la justicia, ésos los devolvéis a Satanás y a los que adoran a Satanás» (Cont. Galil., 229D y E y 230A).

Pero lo más grave no era que los monjes rechazaran todo lo bueno y sabio que podían hallar en las letras profanas, sino que con su ideal educativo «defendido con ahínco por los teóricos del monacato» ponían en entredicho el papel de la ciudad como espacio de socialización por antonomasia y amenazaban con cercenar la continuidad del sistema educativo tradicional. Cuando el cenobitismo se hizo habitual en las tierras del Imperio, a partir de la fórmula impulsada por Pacomio, el proceso quedó completado, ya que el monasterio «se convirtió en la primera comunidad preparada para ofrecer una formación plenamente cristiana a partir de la adolescencia. La asimilación de una cultura literaria enteramente basada en la liturgia y en la Biblia, la modelación del comportamiento siguiendo códigos de conducta afinados por la práctica en los monasterios, y, sobre todo, la formación de jóvenes de ambos sexos a través del ejercicio monástico [...], significaron, por su contenido y aún más por las emociones a que se apelaba en el proceso de socialización, el fin del ideal de la educación recibida en la ciudad y su substitución por el paradigma monástico» ${ }^{18}$.

\section{c) Igualitarismo social}

Con su renuncia radical del mundo y su deseo de recuperar la primitiva condición «adánica» del hombre, el monacato también cuestionaba seriamente

18 P. BROWN, op. cit., p. 285. 
la realidad social y política del Bajo Imperio. Con el propio cristianismo ya se había dado un primer paso hacia la ruptura de las rígidas diferenciaciones sociales pues, en los actos litúrgicos, éstas «podían quedar en suspenso en los momentos más elevados, pero no quedaban nunca completamente abolidas de las mentes de los creyentes, que, una vez terminadas las ceremonias, saldrían de la basílica para volver al duro mundo de la ciudad de la antiguiedad tardía ${ }^{19}$. El ideal monástico, sin embargo, fue más allá: parecía llevar a una nivelacion de las clases sociales definitiva y radical, aunque claramente incompatible con la rígida jerarquización de una sociedad bajorromana en la que el espacio entre potentiores y humiliores se agrandaba a marchas forzadas.

La aspiración última del verdadero monje «cualquiera que fuese su procedencia social» consistía en alcanzar la salvación. Para lograrlo era necesario seguir las consignas dadas por Cristo cuando dijo al joven rico: «Si quieres ser perfecto, ve, vende cuanto tienes, dalo a los pobres, y tendrás un tesoro en los cielos, y ven y sígueme» (Mt. 19, 21). Peró, por encima de todo, resultaba imprescindible procurarse una más íntima comunión con Dios, de ahí la puesta en práctica del ideal de fuga mundi, verdadero elemento definidor del monacato. Apa Alonio había sentenciado: «Mientras el hombre no diga en su corazón: «En este mundo estamos sólo Dios y yo», no tendrá paz ni descanso en su vida» (Verb. Sen, 11, 5). Frente a este objetivo, verdadero pináculo de la vida monástica, las diferenciaciones sociales no debían importar nada; toda otra preocupación «y especialmente las de tipo material» resultaba superflua, e incluso perniciosa para la lucha espiritual del monje. Desde este punto de vista, cualquier cristiano «noble o innoble, rico o pobre» podia sentir la llamada del desierto; a nadie se le debía impedir su ingreso en la vida monástica. He aquí el peligro del ideal monástico: el hecho de que inlustres y subiecti se sometieran a un mismo estado y conviviesen juntos dentro de un sistema, el monástico, que no hacía distingos «al menos teóricamente» entre el origen social de sus miembros. $\mathrm{El}$ monacato, en definitiva, amenazaba con «formar una «clase universal» sin ataduras con la ciudad ni el campo, pues en ambos entomos se es igualmente dependiente de Dios ${ }^{20}$.

Aunque las condiciones de la época y la propia estructura social del Imperio favorecieron, sobre todo, un éxodo masivo de los más débiles hacia el monacato, también hubo vocaciones entre los integrantes de las clases superiores. Y fueron éstas, precisamente, las que más revuelo ocasionaron entre las élites paganas y aún en las cristianas, demasiado imbuidas todavía en las ideas filosófico-poéticas

19 P. BROWN, op. cit., p. 282.

20 P. BRown, op. cit., p. 283.

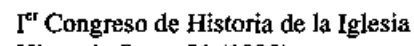
Hispania Sacra 51 (1999) 
propias de la cultura clásica ${ }^{21}$. Los valores culturales y vivenciales de ambas «asentados en un elitismo que se correspondía perfectamente con la clasista realidad social del mundo romano y que buscaba acentuar las distancias que separaban a los notables de sus inferiores» en general chocaron profundamente con el pietismo, la vehemencia y el igualitarismo que iban implícitos en el monacato como forma de vida. Por otro lado, entre los nobles cristianos muchos habían abrazado la cruz por motivos coyunturales «era la religión oficial», más que espirituales, de modo que su comprensión del monacato no difería demasiado de la que tenía la aristocracia pagana. De ahí la sorpresa e indignación que a todos ellos les producían las conversiones monásticas de sus iguales. La dilapidación de los patrimonios, el descuido en el vestir (símbolo importante de la posición social que se ocupaba), la renuncia a los antepasados, el trato continuo con advenedizos y parias, la huida de los cargos y honores seculares...; la adopción de estos nuevos valores por una parte de los dirigentes de la sociedad, podía traer consigo un gravísimo quebranto para el modelo social bajorromano. En este punto, aún más que en los anteriores, la oposición al monacato fue feroz ${ }^{22}$. A propósito de la conversión monástica de Paulino de Nola, y previendo los resultados de la misma, pudo escribir Ambrosio de Milán: «¿Qué dirán los próceres cuando se enteren? ¡Viniendo de tal familia, de tal linaje, de tal condición! Que abandone el Senado un hombre dotado de tan gran elocuencia! ¡Ha interrumpido la sucesión de una noble estirpe! ¡Esto no se puede tolerar! Ellos se raen la cabeza y las cejas cuando se consagran a los misterios de Isis, pero si casualmente un cristiano, más atento a su sagrada religion, cambia de vestido, llaman indigno al hecho» (Epist. 58, 3).

El ideal igualitario del monacato, del que tanto recelaron las clases dirigentes, ya estaba implícito en el mensaje del propio cristianismo. Uno de los más importantes teóricos de la vida monástica, Agustín de Hipona, había quedado impresionado por la facilidad con que los simples podían alcanzar el Reino de los cielos (Confess., 8, 8, 19). Por eso mismo, ¿cómo no iba a ser generoso el monacato con los humildes y los desesperanzados, si sus filas se nutrían mayoritariamente con profesos llegados de esos sectores sociales? ¿Cómo no admitirlos en las filas monásticas? Rechazarlos, según Agustín habría sido un "grave delito», porque «Dios eligió lo débil del mundo» (De oper. monach, 1, 22). Sin embargo, las estructuras sociales y económicas del mundo tardorromano no estaban preparadas para digerir este revolucionario planteamiento. Asentadas sobre una

21 Vid. J. FONTAINE, «Valeurs antiques et valeurs chrétiennes dans la spiritualité des grands propriétaires terriens à la fin du $\Gamma^{*}$ siècle occidentale», en Epektasis. Mélanges patristiques offerts au cardinal Jean Daniélou, (París, 1972), pp. 571-595.

22 Cfr. entre otros, los testimonios de RUTILIO Cl. NAMACIANo, De reditu suo, 515-526; Paulino de Nola, Epistolae, 1, 2-8 y 11, 3; Carmen 10, 278-288 y 330-331; JuAn Crisostomo, Adversus oppugnatores vitae monasticae, 2, 1-2; 2, 10 y 3, 1; JERóNIMO, Epistolae, 38, 5; 39, 6; 45, 4 y 127, 5; EUTROPIO, Epistula ad Genunti filias, de contemnenda haereditate. 
base humana compuesta por esclavos y trabajadores dependientes o adscritos forzosamente a sus oficios, la deserción de éstos habría supuesto el colapso irremediable de tan injusto sistema. Las clases dirigentes del Bajo Imperio, ya fueran paganas o cristianas, podían asumir «no sin reticencias, como ya hemos visto» que sus iguales desertaran de las glonias mundanas para entregarse a Dios, el dominus por antonomasia; pero no estaban dispuestas a tolerar que, al socaire de la vocación monástica, también abandonaran sus puestos quienes estaban sometidos a los patroni terrenales y sostenían con sus hombros el pesado engranaje que mantenía en pie el Imperio. En este punto, la coincidencia de las legislaciones secular, canónica y monástica fue absoluta.

Desde el punto de vista cronológico, la primera medida promulgada para defender el orden vigente partió de la Iglesia y, en concreto, del concilio de Calcedonia de 451 que, en su canon 4 dispuso: "Que en los monasterios no se acepte esclavo alguno para el monacato sin el asentimiento de su señon ${ }^{23}$. Como podemos comprobar, los padres conciliares se mostraron claramente contemporizadores con los intereses económicos y políticos de las clases privilegiadas, dando muestras de esa doble moral que la Iglesia mantuvo respecto a la esclavitud ${ }^{24}$. En este sentido, no resultan consoladoras ni exculpatorias las palabras de Gaudemet cuando, refiriéndose a esta disposición, afirma: «En principe l'Église n'admet pas d'esclave comme moine, non parce qu'elle sous-estime leur condition juridique, mais parce qu'elle respecte les droits du maître» ${ }^{25}$. ¿Se nos acusaría de anacrónicos si preguntásemos de qué sirvió esa «estima» jurídica hacia los esclavos? ¿Dónde quedaron las esperanzas «más retóricas que reales» de Agustín cuando propugnaba una profesión monástica universal?

La Iglesia podría haber dado un paso más hacia adelante, pero no se atrevió. Condescendiente con el siglo, movida por intereses que la vinculaban al sistema establecido «ella misma era una gran propietaria y poseía esclavos cuya manumisión resultaba muy dificultosa, en función del principio de inalienabilidad de su patrimonio», la Iglesia no hizo sino teorizar en este sentido. No puede negarse que en el terreno asistencial realizó una gran tarea; las fuentes cuya enumeración sería aquí demasiado prolija lo demuestran de modo palpable. Sin embargo, la visión de sus dirigentes no fue más allá de una mera concepción caritativa. En la función social de la Iglesia se percibe «una falta total de comprensión de los mecanismos económicos y de la alta función social que la riqueza bien explotada puede jugar en la sociedad, limitándose a unos estre-

23 P. Th. CAMELOT, Éfeso y Calcedonia, Vitoria, 1971, p. 240.

24 R. TEJA, Organización económica y social de Capadocia en el siglo $N$, según los Padres Capadocios, Salamanca, pp. 133-136.

25 J. GAUDEMET, «L'église dans l'Empire Romain (IV'- $V^{e}$ siècles)», en G. LE BRAS (dir), Histoire du Droit et des Institutions de l'Église en Occident, París, 1958, vol. 3. p. 200.

$I^{\text {tre }}$ Congreso de Historia de la Iglesia Hispania Sacra 51 (1999) 
chos límites de moral individual [...]. Parafraseando las palabras de Mazzarino sobre la doctrina social de los padres de la Iglesia podríamos decir que éstos se preocupan más de marcar ideales de vida social que de marcar pautas al estado romano en sus exigencias concretas; se mueven principalmente en el ámbito de un «comunismo caritativo» y de consejos a los ricos a pesar de un fenómeno revolucionario como la «regulación de la pobreza» en los monasterios ${ }^{26}$.

A la legislación eclesiástica siguió la secular, que retomó el mismo principio, pues la autoridad imperial, en su doble condición de posesora y garante del Estado, se mostró también bastante preocupada por la huida al monacato de esclavos y campesinos dependientes. Tres constituciones imperiales, una de Valentiniano III (452) y dos de Zenón (484), fueron promulgadas para regular las profesiones monásticas de esclavos y colonos. En la primera, el emperador les negaba cualquier posibilidad de entrar en el monacato, argumentado que lo harían para escapar de su particular situación jurídica (Novella 35,3 ). En las dos restantes, sin embargo, se dispuso que podrían hacerlo si, previamente, eran manumitidos o liberados de su vínculo de dependencia. Ahora bien, en el supuesto de que abandonaran la vida monástica estaban obligados a volver con sus antiguos dueños (Codex Iustinianus, 1, 3, 36 y 37).

El problema que estas medidas pretendían erradicar no decreció, ni mucho menos, pues unos años después Gelasio I. volvía a reiterar lo ya dispuesto por la tradición canónica y las leyes seculares. La presión de los possessores se percibe una vez más y, de nuevo, vemos a la Iglesia amoldarse a las exigencias coyunturales. En su célebre Decretum generale, el papa prohibía a obispos ý abades que aceptasen en los monasterios a esclavos y colonos originarii fugitivos; sólo en el caso de que hubieran obtenido antes una autorización escrita de su dueño podrían ingresar en el cenobio. $\mathrm{El}$ argumento esgrimido por Gelasio no puede ser más desesperanzador y diáfano: «ne per christiani nominis institutum aut aliena pervadi, aut publica videatur disciplina subverti» ${ }^{27}$.

\section{d) Conclusión}

Hemos visto que, en el ámbito de lo social, la potencialidad revolucionaria del monacato quedó abortada a causa del conservadurismo eclesiástico y civil y de las exigencias que las clases dirigentes impusieron para defender su privilegiada situación. El orden social, tal como se conocía, quedó prácticamente intacto; si acaso, con algunas alteraciones, que afectaron muy poco al conjunto. La sociedad que veremos surgir en la época naciente, salvo en el ámbito de

26 R. TEJA, «La Iglesia y la economía en el siglo IV..., (Cfr. En general, pp. 120-124).

27 El texto del decretum «editado como Epistola 9» en Patr. Lat., 59, cols. 47-57. 
las mentalidades «un tanto prefiguradas ya», no se diferenció demasiado de la que estaba muriendo. Desaparecieron o se reconvirtieron algunos grupos sociales (el de los esclavos, por ejemplo) y las relaciones de dependencia económica y personal subsumieron a un cada vez mayor número de infelices. Pero la dialéctica honestior-humilior que el monacato parecía poner en duda, incluso amenazar, no se modificó; tan sólo adoptó una nueva terminología. En este sentido, el fracaso del ideal monástico igualitario fue patente ${ }^{28}$. ¿Qué ocurrió en los otros dos ámbitos que hemos analizado?

El declive de las ciudades «aunque hoy día no parece acertado hablar de «decadencia urbana», sino de transformación o adecuación funcional de las mismas al nuevo contexto histórico» no fue causado por el monacato. Era una realidad inevitable, impuesta por las circunstancias de la época, que ya se encontraba muy avanzada cuando la vida monástica comenzó a extenderse por la Romania. Por último, en el ámbito cultural, no podían imaginar los paganos que iba a ser precisamente el monacato «sobre todo el occidental» el que se encargaría de conservar y transmitir, debidamente censurado y depurado, el acervo cultural recibido del mundo clásico. No cabe duda que el ideal monástico de la «incultura» tampoco fue responsable de que el universo pagano se hundiera. El proceso lo había iniciado ya la Iglesia en los siglos precedentes y el propio paganismo, atrapado en una dinámica de «esclerotización» progresi va, contribuyo, sin saberlo, a su propia liquidación.

La progresiva implantación de la vida cenobítica «iniciada por Pacomio en Egipto», el surgimiento de las primeras reglas monásticas y la trascendencia de las disposiciones tomadas en el concilio de Calcedonia remansaron las aguas y contribuyeron, decisivamente, a disciplinar la existencia, demasiado amenazante y heterogénea, de los primeros monjes. Se inició así un proceso de institucionalización que habría de convertir al monacato en un «estado» más de la vida cristiana; y aunque los objetivos tardaron tiempo en cumplirse, finalmente se abrió un nuevo y muy fecundo período en las relaciones de éste con la sociedad y con las jerarquías eclesiásticas. Los hechos posteriores demostraron el triunfo indiscutible de estas últimas, al lograr hacer de los monjes un instrumento de primer orden para la expansión del cristianismo durante los siglos altomedievales.

28 Somos conscientes de que la dialéctica monacato - Iglesia jerárquica- poder civil no se desarrolló en unos términos tan radicales como los que acabamos de plantear aquí (llevados por las limitaciones y simplificaciones a que está sometida toda explicación histórica). No cabe duda que en el propio seno del monacato a medida que este se afianzaba como realidad histórica y sin necesidad de que intervinieran los poderes eclesiásticos y civil se desarrollo un proceso reinterpretativo e institu. cionalizador-burocratizador (realidad generalmente inevitable en cualquier empresa humana que dio al traste con buena parte del contenido utópico y revolucionario que la vida monástica encerraba en sus inicios. Vid, al respecto, las valiosas observaciones de I. SEGUY, «Une sociologie des societés imaginées: monachisme el utopie» Annales, $26 / 2$ (1971), pp. 328-354.

$I^{\text {er }}$ Congreso de Historia de la Iglesia

Hispania Sacra 51 (1999) 